\title{
The Kveim test in sarcoidosis
}

\author{
J. R. MiKhaIL \\ Central Middlesex Hospital, London
}

\author{
D. N. MitCheLL \\ M.R.C. Tuberculosis and Chest Diseases Unit, \\ Brompton Hospital, London
}

\begin{abstract}
Summary
The Kveim test with a validated test-suspension was found to give an overall $71.9 \%$ positive result. A very high figure was obtained among patients with hilar or paratracheal gland involvement.

Despite our enumeration of the difficulties and drawbacks inherent in Kveim testing, we find that this is a valuable test, providing one is aware of the pitfalls. Despite the finding of positive tests in conditions other than sarcoidosis, these are unlikely in practice to present a clinical problem in the differential diagnosis of suspected sarcoidosis. A microscopically positive test, therefore, remains clinically valuable.

The test is also of very considerable importance in the clinical research into aetiology and pathogenesis of sarcoidosis.
\end{abstract}

The first published report of the use of a particulate suspension prepared from human sarcoid tissue (lymph node) and used as an intracutaneous test, including an account of the histological features obtained by biopsy of the test site, was given by Kveim in 1941. Suspensions have subsequently been prepared from various affected tissues, spleen being the most suitable as it provides substantial quantities of test material from a single source. Earlier suspensions (consisting of a $1 / 10$ or $1 / 20$ dilution of tissue [wet weight]) were known as 'crude' or 'conventional' suspensions (Nelson, 1948; Danbolt, 1951).

In recent years a Type I Chase-Siltzbach suspension (Chase, 1961) has been more extensively used in international studies. This is more finely particulate, but is still a relatively crude tissue suspension. Only particulate suspensions are active. Although tissue may show relatively fresh granulomata, there is no certainty that this will produce a valid and potent test antigen. Suspensions producing specific reactions can be prepared only from human tissue; the source of such potentially satisfactory material is limited and therefore it is difficult to provide a suspension which can be used as a diagnostic reagent. Each new batch of test material should be tested in parallel with a validated suspension in sarcoid and non-sarcoid patients. Acceptable suspensions by these criteria are few in number and the world supply is therefore limited to a few sources who have validated test material.

The British antigen has been investigated by Dr D. Geraint James and his colleagues and found to be potent in sarcoidosis; more recently a single batch of this material has been validated in a doubleblind study in which the antigen kindly made available by Dr Louis Siltzbach was used as the standard (Mitchell, Sutherland \& Bradstreet, 1969). This antigen (K.12) was found to be of equal potency, giving approximately $70 \%$ positive tests among those patients with clinical sarcoidosis. In cases of tuberculosis and among apparently healthy controls, only $1.5 \%$ showed a positive reaction. Hurley reported at the International Sarcoidosis Conference in Prague (1969) that in the International Kveim Study, $1.7 \%$ showed a positive reaction.

Essentially, the Kveim test consists of an intracutaneous injection, usually about $0.15 \mathrm{ml}$, given on the ulnar aspect of the forearm. Ideally the test site should be marked by a single speck of autoclaved Gunter-Wagner 'Pelikan' ink, just sufficient to break the epidermis at a point well within the raised bleb. Providing only a very minimal amount of this ink is used, no significant foreign body reaction, which might otherwise interfere with the microscopic reading of the test, will result. Siltzbach \& Ehrlich (1954) have shown clearly that biopsy of all test sites, whether or not a visible or palpable reaction is present 4-6 weeks after injection, is obligatory. Otherwise, microscopically positive tests may be missed and conversely a palpable nodule might be due to a 'non-specific' reaction.

The elucidation of the active principle in the Kveim test material and the mechanism of the Kveim reaction are currently the subject of extensive research in several centres and there is little doubt that the finding of this active principle might well contribute to the unsolved prolems of pathogenesis and aetiology of sarcoidosis.

Although we have performed a large number of 
Kveim tests, our remarks today will be confined to eighty-two cases in whom simultaneous mediastinal lymph node biopsy and Kveim test have been carried out.

TABLE 1.

\begin{tabular}{crrrrr}
\hline & \multicolumn{5}{c}{ Kveim } \\
\cline { 3 - 6 } $\begin{array}{l}\text { Radiological } \\
\text { classification }\end{array}$ & Nos. & Positive & Equivocal & Negative & $\%$ \\
\cline { 2 - 6 } & 5 & 2 & 1 & 2 & 40 \\
\hline 0 & 38 & 34 & 0 & 4 & $89 \cdot 5$ \\
1 & 21 & 14 & 1 & 6 & $66 \cdot 6$ \\
2 & 18 & 9 & 1 & 8 & 50 \\
3 & 82 & 59 & 3 & 20 & $71 \cdot 9$ \\
\hline
\end{tabular}

Table 1 shows an analysis of patients tested according to an international radiological classification; this in no way implies a clinical stage, but is used as a convenience of reference.

The radiological staging is as follows:

0 . No pulmonary radiological lesion.

1. Bilateral hilar lymphadenopathy.

2. Bilateral hilar lymphadenopathy + reticulation.

3. Reticulation only.

4. Pulmonary fibrosis.

No case in this series was classified as having pulmonary fibrosis.

All the X-rays in this study were read independently by Professor J. G. Scadding. The Kveim histology was read 'blind' by Dr R. A. B. Drury and Dr D. N. Mitchell.

The overall positive rate was $71.9 \%$. This is higher than the figure of $61 \%$ positive Kveim tests reported by Dr L. Siltzbach in the International Kveim Test Studies (Siltzbach, 1966).

Group 0 consists of patients with extrathoracic sarcoidosis, principally uveitis, and this group without demonstrable radiological lesions was found to have a low incidence of Kveim positivity.

Group 1 consists of cases of bilateral hilar lymphadenopathy, including patients with erythema nodosum. This yielded a very high positive rate $(89 \%)$ as opposed to Dr Hurley's figure of $73 \%$ quoted in the continuing International Kveim Test Study (1969).

The problems of the Kveim test as a purely diagnostic test are centred around the following points:

(1) The limited supply of properly validated test material.

(2) The 4-6 week delay in obtaining a result.
(3) The false-negative gap: at best $10-20 \%$. This increases with duration of the disease. An overall false-negative rate of $40 \%$ is shown by International Studies (30\% in our series). Stated in another way, the Kveim test is most likely to be positive in those cases in which the diagnosis is not in doubt clinically, and there is less likelihood of obtaining a positive test in those cases where the disease may have been present for a considerable period. In other words, where there is a clinical problem of diagnosis, the Kveim test might well be negative.

(4) Positive tests have been reported in Crohn's disease (Mitchell et al., 1969) and in apparently healthy subjects failing to convert to two BCG vaccinations (Mitchell et al., 1967).

(5) Although an apparently simple test, a number of errors of technique can arise which can influence the result.

(6) The difficulty of interpretation of the microscopically 'equivocal' test.

\section{Acknowledgment}

We are indebted to Dr C. M. Patricia Bradstreet, Director, Standards Laboratory for Serological Reagents, Central Public Health Laboratory, Colindale, London, who kindly prepared the test material.

\section{References}

CHASE, M.W. (1961) The preparation and standardisation of Kveim testing antigen. American Review of Respiratory Diseases. 84, 86-8.

Danbolt, N. (1951) On the skin test with sarcoid-tissuesuspension (Kveim's reaction). Acta Dermatovener (Stockholm), 31, 184-93.

Geraint, J.D., Sharma, O.P. \& Bradstreet, P. (1967) The Kveim-Siltzbach Test. Report of a New British Antigen. Lancet, ii, 1274.

HuRLey, T. (1970) Proceedings of Fifth International Conference on Sarcoidosis, Prague. (In press.)

KVEIM, A. (1941) En ny og specifikk kutan-reaksjon ved Boecks sarcoid, en forelobig meddelelse. (On a new and specific cutaneous reaction in Boeck's sarcoid; a preliminary report.) Nordisk Medicin, 9, 169-72.

Mitchell, D.N., Siltzbach, L.E., Sutherland, I. \& Hart, P. d'A. (1967) Proceedings of Fourth International Conference on Sarcoidosis, Paris, p. 154.

Mitchell, D.N., Cannon, P., Dyer, N.H., Hinson, K.F.W. \& WilloughBY, J.M.T. (1969) The Kveim Test in Crohn's disease. Lancet, ii, 571.

Mitchell, D.N., Sutherland, I \& Bradstreet, P. (1969) Proceedings of Fifth International Conference on Sarcoidosis, Prague. (In press.)

Nelson, C.T. (1948) Observations on the Kveim reaction in sarcoidosis of the American Negro. Journal of Investigative Dermatology, 10, 15-26.

Siltzbach, L.E. \& Ehrlich, J.C. (1954) The NickersonKveim reaction in sarcoidosis. American Journal of Medicine, 16, 790-803.

SiltzBaCH, L.E. (1967) An International Kveim test trial (1960-66). Proceedings of Fourth International Conference on Sarcoidosis, Paris, p. 201. 